\title{
Pirates attack US research ship off Somalia
}

\section{Mark Schrope}

A US oceanography research ship has been attacked by pirates in the Gulf of Aden leading its managers to rethink their plans for studying salinity flows in the region.

Unknown, heavily armed assailants pursued the Maurice Ewing research vessel in a small boat for a harrowing 20 minutes in waters 30 kilometres off the coast of Somalia on 31 August. No crew members were hurt and the ship was not damaged.

The Maurice Ewing, which is operated by the Lamont-Doherty Earth Observatory at Columbia University, New York, was in the region for a project called the Red Sea Outflow Experiment (REDSOX). The project involves researchers from the Woods Hole Oceanographic Institution in Massachusetts and the University of Miami in Florida.

"I was frightened, and in a state of disbelief," says Amy Bower of Woods Hole, chief scientist on the mission. "Although I was well aware that this was a region known for piracy, I couldn't believe that our vessel would ever come under fire."

When it first became apparent that the men approaching in a small boat were potentially dangerous, Bower says, all the scientists on the vessel gathered in its main laboratory. "From inside the ship, I don't think anyone heard any shots," she says. "There's just too much background noise - but we watched on a video monitor as crew members on the back deck ducked and we heard over the ship's radio that shots had been fired. It was becoming a much more serious situation, and everyone was ordered to go to their staterooms and lock the doors."

Fire hoses were prepared to repel boarders, Bower says, but the boat gave up the chase.

Mike Purdy, director of Lamont-Doherty, says the expedition was planned in accordance with Department of State security guidelines. These guidelines recommend that ships stay at least 19 kilometres off Somalia's coast, because of the risks of piracy and terrorism. Other research vessels have operated recently in the same area, he says.

"We analysed the risks and made the judgement that it would be a reasonable operating area. We were clearly wrong in that judgement," says Purdy. Nonetheless, he says, the ship's crew handled the situation well, executing predetermined security procedures. He says the crew thinks the attackers fired a grenade, which failed to detonate. The incident has been reported to the state department and the US Navy, but Purdy has no information on the reason for the attack.

As part of REDSOX, researchers completed another cruise in the area in March on the Knorr, operated by Woods Hole. Their goal is to complete the first comprehensive survey of the movement of high-salinity water from

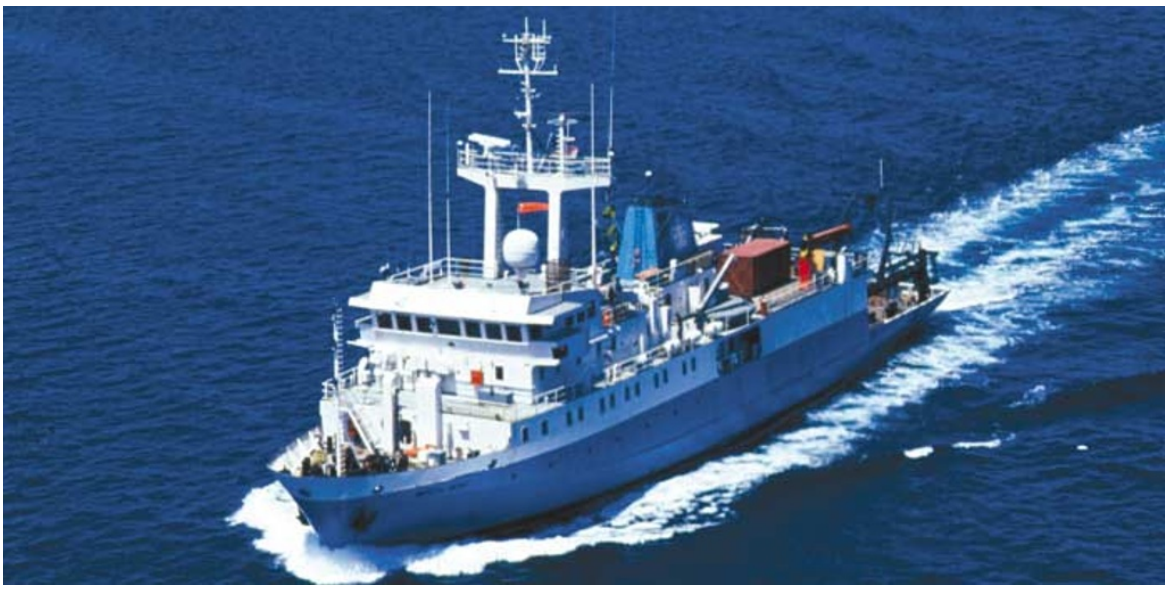

In calmer waters: shots and possibly also a grenade were fired at the Maurice Ewing.

the Red Sea as it mixes with waters in the Gulf of Aden, and eventually the Indian Ocean.

Following consultation with the National Science Foundation, which funded the mission, and others, Purdy authorized the ship to continue working but to stay at least 80 kilometres off the coast. The cruise's first leg is scheduled to end this week in Djibouti.
Extensive work closer to the coast had been scheduled for the second leg, but, says Purdy, "our number one priority right now is the safety of the vessel and the folks on the vessel. We are making substantial modifications to the science plans to ensure that the vessel is never again placed in the dangerous situation in which it found itself."

\section{WHO plans study of Gulf War fallout}

\section{Alison Abbott, Munich}

The World Health Organization (WHO) is to work with Iraqi scientists to assess claims that the incidence of certain diseases has increased in Iraq as a result of NATO's use of weapons containing depleted uranium.

A group of WHO experts visited Iraq late last month to discuss how best to design a study to investigate the claims.

Iraqi scientists say that the use of depleted uranium during the 1991 Gulf War has led to an increased occurrence of at least six types of cancer, and to changes in their characteristics. Renal disease and congenital malformations have also increased, they claim.

Abdelaziz Saleh, from the WHO regional office in Cairo, led the visiting group. "It is not possible to comment on the Iraqi data yet," he says. "But we are preparing a good study design that will allow the questions to be answered definitively."

But definitive answers could be difficult to obtain. An expert on depleted uranium at the Vienna-based International Atomic Energy Agency says the situation in Iraq is an "epidemiological nightmare".

Not only is it unclear whether Iraq has a reliable basis for collecting health data, the expert says, but there are many possible agents that could influence health statistics in postwar Iraq, including poor nutrition and other contaminants left by the war, such as residues from burning oilfields. Moreover, he says, there is no clear account of where the uranium used in the war was deployed.

Barry Smith, of the British Geological Survey, who helped to prepare a WHO report on depleted uranium published in April, says that epidemiology is a useful tool that, together with risk assessment, can help to answer these questions. But such studies require careful investigation of contaminated environments and any potential routes of human exposure. "Both of these can be particularly difficult in post-conflict situations," he says.

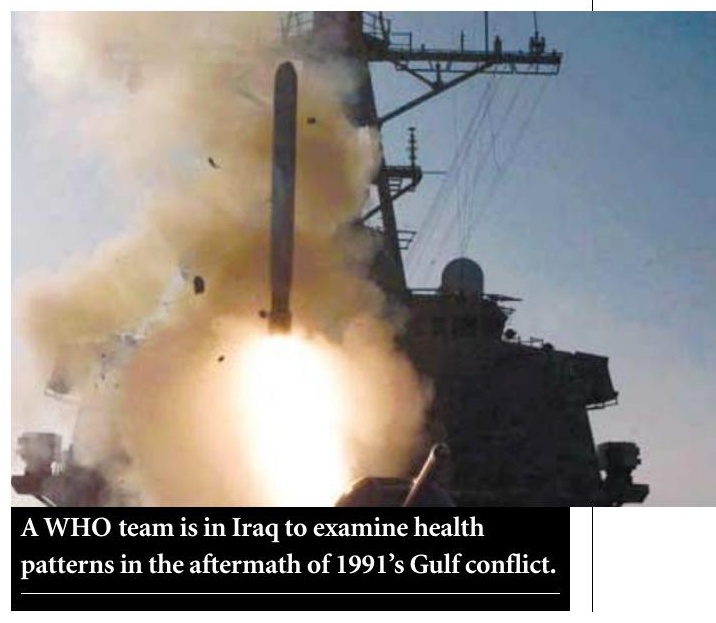

